\title{
Poppy Intoxication in Infants and Children: Hazards of a Folk Remedy
}

\author{
Sumera Akram, Mohammad Fazil and Kiramat Ullah \\ Department of Paediatrics, Mardan Medical Complex, Mardan, Pakistan
}

\begin{abstract}
Objective: To study the clinical and laboratory profile in infants and children presented in the tertiary care hospital with poppy intake and to compare the profile between those who survived with those who died.

Study design: Observational study.

Study Place and Duration: Department Of Paediatrics, Mardan Medical Complex, Mardan, KPK, Pakistan from January 2019 to January 2020.

Methodology: All the infants and children who reported during research period with signs and symptoms (one or more) of opium poppy intoxication, i.e. meiosis, respiratory depression and decreased consciousness level along with confirmed history of giving poppy at home.

Results: A total of 32 cases of opium poppy intoxication were admitted. Their age ranged from one month to 23 months, mean age was $7.22 \pm 5.43$ months. Out of them, $15(46.87 \%)$ infants and children survived, and $17(53.13 \%)$ died, $(p<0.001)$. The children who survived had significantly shorter period of time between poppy over-dose and admission in hospital as compared to those who had died $(6.0 \pm 2.56$ hours versus $12.47 \pm 4.14$ hours, $p<0.001)$. There was significantly high mortality in children who were given poppy powder mixed in water, out of 17 cases 13 died and 4 survived. Low respiratory rate, decreased oxygen saturation, aspiration pneumonia, apneic spells, cyanosis and leukocytosis $>15000 \mathrm{cc}$ had significant effect on mortality.

Conclusion: Poppy opium is very dangerous and hazardous for infants as it depresses respiration, causes coma; and can be fatal. People need to be educated to curb this harmful practice and authorities need to take necessary actions to stop the sale of poppy at shops and stores.
\end{abstract}

Key Words: Poppy, poisoning/Intoxication, Infants, Meiosis, Apneic spell.

How to cite this article: Akram S, Fazil M, Ullah K. Poppy Intoxication in Infants and Children: Hazards of a Folk Remedy. J Coll Physicians Surg Pak 2021; 31(05):576-581.

\section{INTRODUCTION}

The opium poppy plant Papaver Somniferous L. was described by Hippocrates as hypnotic, cathartic and styptic (stops bleeding of wounds) more than 350 years BC. ${ }^{1}$ Poppies are traditional source of analgesics, ant food, anti-malarials, aphrodisiacs, rattles for baby, anti-tussives, diaphoretics, anti-diarrheal, hemostatics, hypnotics, salad vegetables, tranquilisers etc. ${ }^{1}$ Poppy plant contains many alkaloids including morphine, codeine, narcotine, papaverine, thebaine, narcotoline and narceine. ${ }^{2}$ Majority of alkaloids are in poppy milk-opium. It is prepared by drying and processing the juice exctracted from fine cuts along premature poppy heads. ${ }^{3}$ It has been used for pain relief and cough. Poppy seeds are traditionally used in Pakistan as food. They normally do not contain alkaloids, but pest damage or rough harvesting can contaminate seeds with opium alkaloids. ${ }^{4}$

Correspondence to: Dr. Sumera Akram, Department of Paediatrics, Mardan Medical Complex, Mardan, Pakistan E-mail: sumera_ak@yahoo.com

Received: February 22, 2020; Revised: October 19, 2020; Accepted: November 27, 2020

DOI: https://doi.org/10.29271/jcpsp.2021.05.576
It is known that pharmacokinetics of morphine are same in adults and children. ${ }^{4}$ But, neonates and infants show significantly different pharmacokinetics and display longer half-life of morphine, high volume of its distribution, decreased plasma clearance and less protein binding. ${ }^{5}$ In addition, they also have immature blood brain barrier resulting in elevated morphine concentrations in their brain and eventually higher risk of notorious effects. After one year of age, pharmacokinetics of morphine becomes similar for both adults and neonates and infants. ${ }^{6}$ Because of these reasons, chances of morphine toxicity and adverse effects are higher in neonates and infants.

Generally, because of risk of serious side effects, paediatric use of morphine for chronic pain management more than three months is considered life-threatening. ${ }^{7}$ Morphine can also cause apnoea and seizures in neonates and infants. ${ }^{8}$ Other common alkaloid found in poppy is codeine. Intoxication of codeine has almost same symptoms as those of morphine, showing metabolism of codeine to morphine. ${ }^{8}$ Most common symptoms include respiratory depression, sleepiness, stupor, pulmonary oedema, meiosis, vomiting, cyanosis etc. ${ }^{9}$ In this country, people often misuse poppy for coughing and crying infants and babies, which can lead to toxicity and even death. 
Table I: Clinical and laboratory profile of cases of poppy poisoning $(n=32)$.

\begin{tabular}{|c|c|c|c|}
\hline \multicolumn{3}{|l|}{ Profile } & Result \\
\hline \multicolumn{3}{|l|}{ Age (in months) } & $\begin{array}{l}\text { Mean } 7.22 \pm 5.43 \text { month } \\
\text { Min } 01 \text { month to } 23 \text { month }\end{array}$ \\
\hline \multirow{2}{*}{\multicolumn{2}{|c|}{ Outcome }} & Survived & 15 cases $(46.87 \%)$ \\
\hline & & Died & 17 cases $(53.13 \%)$ \\
\hline \multirow{2}{*}{\multicolumn{2}{|c|}{ Gender }} & Males & $14(43.8 \%)$ \\
\hline & & Females & $18(56.3 \%)$ \\
\hline \multirow{4}{*}{\multicolumn{2}{|c|}{ Main reason of giving poppy }} & Fever and cough & 4cases $(12.5 \%)$ \\
\hline & & Cough & 7 cases $(21.9 \%)$ \\
\hline & & Excessive cry & 9 cases $28.1 \%)$ \\
\hline & & Excessive cry and cough & 12 cases $(37.5 \%)$ \\
\hline \multirow{2}{*}{\multicolumn{2}{|c|}{ Form of giving poppy }} & Powder form mixed in water & 15 cases $(46.9 \%)$ \\
\hline & & Poppy pods boiled in water & 17 cases $(53.1 \%)$ \\
\hline \multicolumn{3}{|c|}{ Time duration (hours) from intake of poppy to reach the hospital } & $\begin{array}{l}\text { Mean } 9.44 \pm 4.75 \mathrm{hrs} \\
\text { Min } 2 \text { hours to } \max 19 \text { hours }\end{array}$ \\
\hline \multirow{8}{*}{\multicolumn{2}{|c|}{ Clinical findings }} & Temperature ${ }^{\circ} \mathrm{C}$ & $\begin{array}{l}37.50 \pm 0.60^{\circ} \mathrm{C} \\
\operatorname{Min} 36.5^{\circ} \mathrm{C}, \operatorname{Max} 39.1^{\circ} \mathrm{C}\end{array}$ \\
\hline & & Oxygen saturation & $\begin{array}{l}\text { Mean }=87.3+5.82 \% \\
\text { Min }=76 \%, \text { Max }=95 \%\end{array}$ \\
\hline & & Meiosis & 32 cases $(100 \%)$ \\
\hline & & Low respiratory rate & 27 cases $(84.4 \%)$ \\
\hline & & Seizures & 19 cases $(59.4 \%)$ \\
\hline & & Altered sensorium & Cases $32(100 \%)$ \\
\hline & & Apneic spells & 18 cases $(56.3 \%)$ \\
\hline & & Aspiration pneumonia & 17 cases $(53.1 \%)$ \\
\hline \multirow{8}{*}{\multicolumn{2}{|c|}{ Laboratory findings }} & Hemoglobin $\leq 9 \mathrm{gm} \%$ & 20 cases $(62.5 \%)$ \\
\hline & & Leucocytosis $\geq 15000 / \mathrm{ml}$ & 21 cases $(65.6 \%)$ \\
\hline & & Hypernatremia $\geq 150 \mathrm{mEq} / \mathrm{L}$ & 4 cases $12.5(\%)$ \\
\hline & & Hyponatremia $\leq 135 \mathrm{mEq} / \mathrm{L}$ & 1 cases $(3.1 \%)$ \\
\hline & & Hyperkalemia $>5 \mathrm{mEq} / \mathrm{L}$ & 5 cases $(15.6 \%)$ \\
\hline & & Hypokalemia <3.5 mEq/L & 2cases $6.3(\%)$ \\
\hline & & Serum urea $>40 \mathrm{mg} \%$ & 4 cases $(12.5 \%)$ \\
\hline & & Serum CPK $\geq 500 \mathrm{u} / \mathrm{L}$ & 6 cases $(18.8 \%)$ \\
\hline \multirow{2}{*}{ Education status } & Mother & $\begin{array}{l}\text { Uneducated } \\
\text { Educated }\end{array}$ & $\begin{array}{l}23 \text { cases }(71.9 \%) \\
9 \text { cases }(28.1 \%)\end{array}$ \\
\hline & Father & $\begin{array}{l}\text { Uneducated } \\
\text { Educated }\end{array}$ & $\begin{array}{l}20 \text { cases }(62.5 \%) \\
12 \text { cases }(37.5 \%)\end{array}$ \\
\hline \multicolumn{2}{|c|}{ Socioeconomic status } & $\begin{array}{l}\text { Poor class } \\
\text { Middle class }\end{array}$ & $\begin{array}{l}24 \text { cases }(75 \%) \\
8 \text { cases }(25 \%)\end{array}$ \\
\hline \multicolumn{2}{|l|}{ Father job status } & $\begin{array}{l}\text { Jobless } \\
\text { Employed }\end{array}$ & $\begin{array}{l}5 \text { cases }(15.6 \%) \\
27 \text { cases }(84.4 \%)\end{array}$ \\
\hline \multicolumn{2}{|l|}{ Mother job status } & $\begin{array}{l}\text { Housewife } \\
\text { Employed }\end{array}$ & $\begin{array}{l}28 \text { cases }(87.5 \% \\
4 \text { cases }(12.5 \%)\end{array}$ \\
\hline \multicolumn{2}{|c|}{$\begin{array}{l}\text { Number of siblings in the } \\
\text { family }\end{array}$} & $\begin{array}{l}\text { Four or more } \\
\text { Less than four }\end{array}$ & $\begin{array}{l}17 \text { cases }(53.1 \%) \\
15 \text { cases }(46.9 \%)\end{array}$ \\
\hline
\end{tabular}

The research has been done to study the clinical and laboratory profile in infants and children presented in the tertiary care hospitals with poppy intake and to compare the profile between those who survived with those who died.

\section{METHODOLOGY}

The study was carried out from January 2019 to January 2020 at Mardan Medical Complex, KPK, Pakistan after approval from local Ethical Committee. Informed consent was also taken from parents. The children having one or more clinical features of opium toxicity, i.e. meiosis, low respiratory rate, decreased level of consciousness \pm seizures, vomiting along with history of intake of opium poppy at home were included in the study. The children who were administered opioids (morphine etc.); and neonates, whose mothers were on opioid analgesics, were excluded.
The data including age, gender, clinical presentation, reason of giving opium poppy to cases, method of opium toxicity (method of preparing and giving opium poppy to infants/children), parent's education standards, parent's employment status, socioeconomic status, number of siblings per family, time to reach hospital after intake and outcome of cases, were assessed and analysed. Education status was categorised into uneducated and educated. Socioeconomic status was categorised into poor/lower class, middle class and high class/wealthy. Employment status was categorised into unemployed and employed. For mothers, employment status was categorised into housewife and employed. All other cases of encephalitis, septic shock, seizures, drug overdose, etc. were excluded after careful history, examintion and assessment.

SPSS version 21 was used to analyse data. Percentages was used to express frequencies, Chi-square test was used to analyse qualitative variables. 
Table II: Effect of various factors on outcome in cases of poppy poisoning.

\begin{tabular}{|c|c|c|c|c|}
\hline Factor & Total $(\mathrm{N}=32)$ & $\begin{array}{l}\text { Group A (Survived) } \\
\mathrm{N}=15\end{array}$ & $\begin{array}{l}\text { Group B (Died) } \\
\mathrm{N}=17\end{array}$ & p-value \\
\hline Age (in months) & Mean \pm SD: $7.22+5.43$ & $7.77+4.94$ & $6.74 \pm 5.92$ & $P=0.600$ \\
\hline Gender & $\begin{array}{l}\text { Male: } \\
14(43.75 \%) \\
\text { Females: } \\
18(56.25 \%)\end{array}$ & $\begin{array}{l}5(33.33 \%) \\
10(66.67 \%)\end{array}$ & $\begin{array}{l}9(52.94 \%) \\
8(57.06 \%)\end{array}$ & $P=0.308$ \\
\hline \multirow{4}{*}{ Main reason of giving poppy } & $\begin{array}{l}\text { Cough: } \\
07(21.87 \%)\end{array}$ & $6(40.0 \%)$ & $1(5.88 \%)$ & \multirow{4}{*}{$P=0.005$} \\
\hline & $\begin{array}{l}\text { Excessive cry: } \\
09(28.12 \%)\end{array}$ & $6(40.0 \%)$ & $3(17.64 \%)$ & \\
\hline & $\begin{array}{l}\text { Cough \& excessive cry: } \\
12(37.50 \%)\end{array}$ & $1(6.67 \%)$ & $11(64.71 \%)$ & \\
\hline & $\begin{array}{l}\text { Fever and cough: } \\
4(12.50 \%)\end{array}$ & $2(13.33 \%)$ & $2(11.76 \%)$ & \\
\hline \multirow{2}{*}{ Form of giving poppy } & Poppy pods boiled in water (17 53.13\%) & $13(86.67 \%)$ & $4(23.53 \%)$ & \multirow{2}{*}{$p<0.001$} \\
\hline & Poppy powder mixed In water (15 46.87\%) & $2(13.33 \%)$ & $13(76.47 \%)$ & \\
\hline $\begin{array}{l}\text { Time duration (hours) from intake of poppy to reach } \\
\text { the hospital }\end{array}$ & $9.44 \pm 4.75$ hours & $6.00 \pm 2.56$ hours & $12.47 \pm 4.14$ hours & $p<0.001$ \\
\hline \multirow{9}{*}{ Clinical findings } & $\begin{array}{l}\text { Temperature }{ }^{\circ} \mathrm{C}: \\
37.50 \pm 0.60\end{array}$ & $37.49 \pm 0.59^{\circ} \mathrm{C}$ & $37.51 \pm 0.63^{\circ} \mathrm{C}$ & \\
\hline & $\begin{array}{l}\text { Oxygen saturation: } \\
87.3 \% \pm 5.82\end{array}$ & $92.47 \pm 1.81 \%$ & $82.82 \pm 4.07 \%$ & $p<0.001$ \\
\hline & $\begin{array}{l}\text { Meiosis } \\
32(100 \%)\end{array}$ & $15(100 \%)$ & $17(100 \%)$ & \\
\hline & $\begin{array}{l}\text { Respiratory depression: } \\
7(84.38 \%) \text { Yes } \\
5(15.62 \%) \text { No }\end{array}$ & $\begin{array}{l}10(66.67 \%) \\
5(33.33 \%)\end{array}$ & $\begin{array}{l}17(100 \%) \\
0(0 \%)\end{array}$ & $P=0.015$ \\
\hline & $\begin{array}{l}\text { Seizures: } \\
\text { 19(59.38\%) Present } \\
\text { 13(40.62\%) Absent }\end{array}$ & $\begin{array}{l}8(53.33 \%) \\
7(46.67 \%)\end{array}$ & $\begin{array}{l}11(64.71 \%) \\
6(35.29 \%)\end{array}$ & \\
\hline & $\begin{array}{l}\text { Altered sensorium: } \\
32(100 \%)\end{array}$ & $15(100 \%)$ & $17(100 \%)$ & \\
\hline & $\begin{array}{l}\text { Apneic spells: } \\
\text { 18(56.25\%) Present } \\
\text { 14(43.75\%) Absent }\end{array}$ & $\begin{array}{l}5(33.33 \%) \\
10(66.67 \%)\end{array}$ & $\begin{array}{l}13(76.47 \%) \\
4(23.53 \%)\end{array}$ & $P=0.031$ \\
\hline & $\begin{array}{l}\text { Aspiration pneumonia: } \\
\text { 17(53.13\%) Present } \\
\text { 15(46.87\%) Absent }\end{array}$ & $\begin{array}{l}3(20.0 \%) \\
12(80.0 \%)\end{array}$ & $\begin{array}{l}14(82.35 \%) \\
3(17.65 \%)\end{array}$ & $P=0.001$ \\
\hline & $\begin{array}{l}\text { Cyanosis: } \\
17(53.13 \%) \text { Yes } \\
15(46.87 \%) \text { No }\end{array}$ & $\begin{array}{l}2(13.33 \%) \\
13(86.67 \%)\end{array}$ & $\begin{array}{l}15(88.24 \%) \\
2(11.76 \%)\end{array}$ & $p<0.001$ \\
\hline \multirow{8}{*}{ Laboratory findings } & $\begin{array}{l}\text { Hemoglobin } \leq 9 \mathrm{gm} \% \\
20(62.50 \%) \text { yes } \\
12(37.50 \%) \text { No }\end{array}$ & $\begin{array}{l}9(60 \%) \\
6(40 \%)\end{array}$ & $\begin{array}{l}11(64.71 \%) \\
6(35.29 \%)\end{array}$ & \\
\hline & $\begin{array}{l}\text { Leucocytosis } \geq 15000 / \mathrm{ml} \\
21(65.62 \%) \text { Yes } \\
11((34.38 \%) \text { No }\end{array}$ & $\begin{array}{l}6(40 \%) \\
9(60 \%)\end{array}$ & $\begin{array}{l}15(88.24 \%) \\
2(11.76 \%)\end{array}$ & $P=0.008$ \\
\hline & $\begin{array}{l}\text { Hypernatremia } \geq 150 \mathrm{mEq} / \mathrm{L} \\
4(12.50 \%) \text { Yes } \\
28(87.50 \%) \text { No }\end{array}$ & $\begin{array}{l}2(13.33 \%) \\
13(86.67 \%)\end{array}$ & $\begin{array}{l}2(11.76 \%) \\
15(88.24 \%)\end{array}$ & \\
\hline & $\begin{array}{l}\text { Hyponatremia } \leq 135 \mathrm{mEq} / \mathrm{L} \\
1(3.13 \%) \text { Yes } \\
31((96.87 \%) \text { No }\end{array}$ & $\begin{array}{l}0(0 \%) \\
15(100 \%)\end{array}$ & $\begin{array}{l}1(5.88 \%) \\
16(94.12 \%)\end{array}$ & \\
\hline & $\begin{array}{l}\text { Hyperkalemia >5 mEq/L } \\
5(15.63 \%) \text { Yes } \\
27((84.37 \%) \text { No }\end{array}$ & $\begin{array}{l}1(6.67 \%) \\
14(93.33 \%)\end{array}$ & $\begin{array}{l}4(23.53 \%) \\
13(76.47 \%)\end{array}$ & \\
\hline & $\begin{array}{l}\text { Hypokalemia<3.5 mEq/L } \\
2(6.25 \%) \text { Yes } \\
30(93.75 \%) \text { No }\end{array}$ & $\begin{array}{l}2(13.33 \%) \\
13(86.67 \%)\end{array}$ & $\begin{array}{l}0(0 \%) \\
17(100 \%)\end{array}$ & \\
\hline & $\begin{array}{l}\text { Serum urea }>40 \mathrm{mg} \% \\
4(12.50 \%) \text { Yes } \\
28(87.50 \%) \text { No }\end{array}$ & $\begin{array}{l}3(20 \%) \\
12(80 \%)\end{array}$ & $\begin{array}{l}1(5.88 \%) \\
16(94.12 \%)\end{array}$ & \\
\hline & $\begin{array}{l}\text { Serum CPK } \geq 500 \mathrm{u} / \mathrm{L} \\
6(18.75 \%) \text { Yes } \\
26(81.25 \%) \text { No }\end{array}$ & $\begin{array}{l}3(20 \%) \\
12(80 \%)\end{array}$ & $\begin{array}{l}3(17.65 \%) \\
14(82.35 \%)\end{array}$ & \\
\hline
\end{tabular}

Table III: Other factors affecting the outcome of poppy poisoning cases.

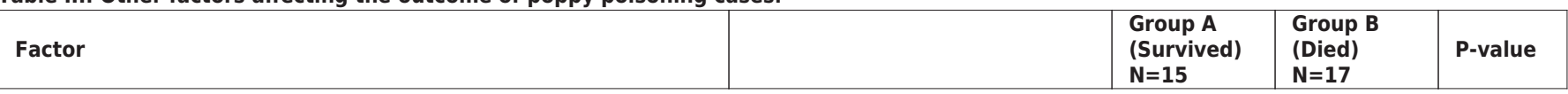




\begin{tabular}{|c|c|c|c|c|}
\hline \multirow[t]{2}{*}{ Education mother } & $\begin{array}{l}\text { Uneducated } \\
23(71.88 \%)\end{array}$ & $11(73.33 \%)$ & $12(70.59 \%)$ & \multirow[b]{2}{*}{$P=1.00$} \\
\hline & $\begin{array}{l}\text { Educated } \\
9(28.12 \%)\end{array}$ & $4(26.67 \%)$ & $5(29.41 \%)$ & \\
\hline \multirow{2}{*}{ Education father } & $\begin{array}{l}\text { Uneducated } \\
20(62.50 \%)\end{array}$ & $10(66.67 \%)$ & $10(58.82 \%)$ & \multirow[b]{2}{*}{$P=0.726$} \\
\hline & $\begin{array}{l}\text { Educated } \\
12(37.50 \%)\end{array}$ & $5(33.33 \%)$ & $7(41.18 \%)$ & \\
\hline \multirow{2}{*}{ Mother job } & $\begin{array}{l}\text { Housewife } \\
28(87.50 \%)\end{array}$ & $13(86.67 \%)$ & $15(88.24 \%)$ & \multirow[b]{2}{*}{$P=1.00$} \\
\hline & $\begin{array}{l}\text { Employed } \\
4(12.50 \%)\end{array}$ & $2(13.33 \%)$ & $2(11.76 \%)$ & \\
\hline \multirow{2}{*}{ Father job } & $\begin{array}{l}\text { Jobless } \\
5(15.63 \%)\end{array}$ & $2(13.33 \%)$ & $3(17.65 \%)$ & \multirow[b]{2}{*}{$P=1.00$} \\
\hline & $\begin{array}{l}\text { Employed } \\
27(84.37 \%)\end{array}$ & $13(86.67 \%)$ & 14(82.35\%) & \\
\hline \multirow{2}{*}{ Socioeconomic status } & $\begin{array}{l}\text { Poor } \\
24(75 \%) \\
\end{array}$ & $13(86.67 \%)$ & $11(64.71 \%)$ & \multirow[b]{2}{*}{$P=0.229$} \\
\hline & $\begin{array}{l}\text { Middle class } \\
8(25 \%)\end{array}$ & $2(13.33 \%)$ & $6(35.29 \%)$ & \\
\hline \multirow{2}{*}{ Siblings } & $\begin{array}{l}\text { Number of siblings } \\
\geq 417(53.13 \%)\end{array}$ & $1(6.67 \%)$ & $16(94.12 \%)$ & \multirow{2}{*}{$P<0.001$} \\
\hline & $\begin{array}{l}\text { Number of siblings } \\
<415(46.88 \%)\end{array}$ & 14(93.33\%) & $1(5.88 \%)$ & \\
\hline
\end{tabular}

Quantitative variables were expressed as mean along with standard deviation and independent t-test was used for quantitative variables. A p-value less than 0.05 was considered significant.

Normality of all quantitative variables were checked by Kolmogorov-Smrinov test; and Shapiro-wilk test was applied and variables found to be normally distributed.

\section{RESULTS}

A total of 32 cases of poppy opium toxicity came to study during the period. Their age ranged from one month to 23 months, mean age was $7.22 \pm 5.43$ month. There were 14 males and 18 females. Out of them, 15 (46.87\%) infants and children survived, 17 (53.13\%) died. All the cases were given poppy at home as a folk remedy for various purposes as shown in Table I. Most common cause of giving poppy was excessive cough and cry (12 cases), followed by excessive cry (9 cases), cough ( 7 cases) and fever with cough (4 cases). People gave poppy to infants and children in powder form after grinding the poppy pods and then mixing with small quantity of water (15 cases) or after boiling poppy pods in water and then feeding the infants and children (17 cases). Time duration from intake of poppy to reach hospital varied from minimum 02 hours to maximum 19 hours, mean time was $9.44 \pm 4.75$ hours. Mean temperature of cases was $37.50 \pm 0.60{ }^{\circ} \mathrm{C}$. Mean oxygen saturation was $87.3 \pm 5.82 \%$. All the cases had meiosis (constriction of pupils) and altered sensorium. Seizures were observed in 19 cases, apneic spells in 18 cases and aspiration was seen in 17 cases, as shown in Table I.

Laboratory findings of anemia, raised leucocyte count, electrolyte imbalances, raised urea and CPK (creatinine phosphokinase) have also been mentioned in Table II. Twenty-four cases belonged to poor socioeconomic background, and 8 belonged to middle class; however, none was from high class. Education status of parents job status of parents, and family size are shown in Table III.

All the infants, who were in critical condition, had altered sensorium and meiosis. Majority had other clinical scenarios as mentioned above. Naloxone is antidote for opium. Naloxone was given in all cases to reverse the effects of morphine alkaloid in opium. Dose of naloxone was 0.1 $\mathrm{mg} / \mathrm{kg}$. In few cases, naloxone was even repeated to reverse the effects of opium in poppy and maintain reversal. Effects of various factors on outcome (died or survived) have been assessed in Table II and III. Mean age of infants and children in group $A$ (who survived) was7.77 \pm 4.94 months as compared to $6.74 \pm 5.92$ months in group $B$ (who died), but the difference was not significant $(p=0.600)$. There were 5 males and 10 females in Group A (survived) and 9 males and 8 females in Group B (who died), $p=0.308$. There was strong association between reason of poppy giving and outcome, i.e death or survival. Out of 12 cases with history of cough and excessive cry, 11 died and 01 survived; $p$ value 0.005 . However, rest of complaints, i.e cough ( 6 survived and 01 died), cry (6 survived and 3 died) and fever with cough ( 2 survived and 2 died) had more survivals as shown in Table II. There was also significantly high mortality in children who were given poppy powder mixed in water (prepared by grinding poppy pods then mixed with water), out of 17 cases 13 died and 4 survived. However, the children who were given boiled water of poppy pods had better survival (13 survived versus 4 died), $p<0.001$. Another important factor affecting survival was time duration to reach hospital. The mean time of children (who survived) to reach hospital was $6.0 \pm 2.56$ hours as compared to Group B (who died) who 
had mean time of $12.47 \pm 4.14$ hours, $p<0.001$. Among the clinical features, low respiratory rate, oxygen saturation, aspiration pneumonia, apneac spells and cyanosis had significant effect on mortality as shown in Table II. Among laboratory investigations, children who had leucocytosis $>15000 c c$ had significant mortality $(p=0.005)$; however, rest of Lab findings including low hemoglobin, hyponatremia, hypernatremia, hypokalemia, hyperkalemia, raised serum urea, and raised CPK (creatinine phosphokinase) had insignificant association with outcome. Altered sensorium and meiosis were constant; therefore, $p$ value could not be calculated for these factors.

Other factors including education status of parents, job status of parents, and socioeconomic status had no significant association with outcome, i.e mortality versus survival. However, the infants and children who had 4 or more number of siblings, had significantly high number of deaths, i.e. 16 died and 01 survived $(p<0.001)$ as shown in Table III.

\section{DISCUSSION}

Because of easy availability of opium poppy in our country, its toxicity is not rare. Parents give poppy to infants and children in different forms for common colds, cough, crying, coryza, restlessness, abdominal colics; and it can result in overdose and even toxicity/poisoning. Opium (opiod) toxicity in children is quite serious; and without timely intervention, can cause death. ${ }^{10,11}$ Easy availability, cheap price and old traditional history of opium poppy are deep- rooted socially acceptable factors of using opium for minor complaints, e.g crying etc. The presence of decreased level of consciousness, meiosis and decreased respiratory effort or apnoea should raise suspicion of opium toxicity. ${ }^{12}$ In this study, mortality of poppy poisoning was $53.13 \%$ among infants and children. Most common cause of poppy ingestion was cough and excessive cry (seen in $37.50 \%$ of cases) and poppy was given to cases after boiling poppy pods in water (53.13) or mixing the powdered poppy in water (46.87\%).

Ghaemi et al. reported 31 cases of opium poisoning in Iran during 2014/2015; these cases had been given opium overdose for curing cough, diarrhoea, colic and restlessness. ${ }^{11}$ Zamani et al had reported total 228 infants and 82 toddlers, were admitted in Loghman Hakim Hospital, Iran from 2001 to 2009 with opium toxicity. Out of these, 67 cases were result of accidental opium ingestion; however, 169 cases were overdosed consequent to folk remedy for diarrhoea, cold, cough, restlessness and fever. ${ }^{13}$ Accidental opium ingestion occurs when children ingest opioid drugs out of curiousity (lying within their reach due to carelessness of parents) or when parents/caregivers mistakenly give opioid instead of other drug. Imran et al. published local data with 22 infants of opium poisoning admitted in Lady Reading Hospital, Peshawar in $1979 .{ }^{14}$ All the cases had typical history of opium (poppy) usage as remedy at home followed by drowsiness, cyanosis, seizures, restlessness, etc. Ira Shah reported a case of opium toxicity in India in $2012 .{ }^{16}$ The frequency of infants with opium intoxication has reduced gradually over period of time. ${ }^{14-16}$

In this study, educational status of parents did not have any significant effect on outcome of poppy poisoning. However, large families ( $>4$ children) had significantly higher chances of mortality than those with less children. Water source contamination with poppy can also be a risk factor, especially in the community where water source is near poppy plants/field. People need to be educated to curb use of poppy for remedial or recreational purpose, etc. It is a serious public health issue. Authorities should play effective role by banning its cultivation and sale at stores.

\section{CONCLUSION}

Poppy-opium is given by parents to infants and children as a remedy to cure common cold, cough, crying and restlessness. Poppy opium is very dangerous and hazardous for infants and children as it depresses respiration, causes coma; and can be fatal. People need to be educated to curb this harmful practice; and authorities need to take necessary actions to stop sale of poppy at shops and stores. Proper hygiene and family planning plays an important role in decreasing morbidity and mortality of paediatric population.

\section{ETHICAL APPROVAL:}

Ethical approval was obtained from the Ethical Review Board of the Hospital prior to the start of subject research.

\section{PATIENTS' CONSENT:}

Patients' consents were obtained from the parents regarding publishing the data concerning their cases.

\section{CONFLICT OF INTEREST:}

The authors declared no conflict of interest.

\section{AUTHORS' CONTRIBUTION:}

SA: Conceived the idea, actively collected data, managed these poppy poisoning cases, and wrote the script.

MF: Collected data and managed these cases.

$\mathrm{KU}$ : Assisted in management of the cases and helped in data analysis \& revision.

\section{REFERENCES}

1. Duke JA. Utilization of Papaver. Economic Botany, Vol 27, No 4, 1973. Pp 390-400. JSTOR. www.jstor.org/stable/4253448. [Accessed on Jan 20, 2020].

2. Kwiecein-Obara E, Szaponar J, Krajewska A, Witkowska A, Radoniewicz A, Szponar M. Morphine (obtained from poppy seeds) and dextrometorfan poisoning- a case report. PrzegladLekarski 2015; 73(8): 596-8.

3. European Safety Food Authority. Opium alkaloid in poppy 
seeds: assessment updated. 16 may 2018. Accessed online 23 January 2020. http://www.efsa.europa.eu/en/press/ news/180516

4. Martindale 2017. The complete drug reference. Morphine: Online. Pharmaceutical press, London. Available online: http://www.medicinescomplete.com/mc/martindale/current/.

5. Kesawan K. Neurodevelopmentalimplications of neonatalpain and morphine exposure. Pediatr Annals 2015; 44: e260-264. doi: 10.3928/00904481-20151112-08.

6. Lyon C, Njoku DB. Anesthetic pharmacology: physiologic states, pathophysiologic states and adverse effects. Essentials of Pediatric Anesthesiology 2015; 27-37. doi: 10.1017/CBO9781107375338.005.

7. Berde CB, Walco GA, Krane EJ, Anand KJS, Arnada JV, Craig KD et al. Pediatric analgesic clinical trials designs, measures, and extrapolation: Report of an FDA scientific workshop. Pediatrics 2012; 129:354-64. doi: 10.1542/ peds.2010-3591.

8. Knutson HK, Alexander J, Barregard L, Bignami M, Bruschweiler B, Ceccatelli $S$, et al. Update of the scientific opinion on opium alkaloids in poppy seeds. EFSA J 2018; 16(5): 5243. doi: 10.2903/j.efsa.2018.5243.
9. Dillon R, Johnston PC, Daly G. Codeine induced pulmonary edema (an unusual case of dyspnea). QMJ 2013; 106: 189-290. doi: 10.1093/qjmed/hcs022.

10. Sachdeva DK, Stadnyk JM. Are one or two dangerous? Opiod exposure in toddlers. J Emerg Med 2005; 29:77-84. doi: 10.1016/j.jemermed.2004.12.015.

11. Ghaemi N, Alikhani S, Bagheri S, Sezavar M. A cross sectional study on opiod poisoning in children at a tertiary care center. Asia Pac J Med Toxicol 2016; 5:115-8. doi: 10.22038/apjmt.2016.8136.

12. Boyer EW. Management of opiod analgesic overdose. $\mathrm{N}$ engl J Med 2012; 367: 146-55. doi: 10.1056/NEJMra1202561.

13. Zamani N, Sanaei-Zadeh H, Mostafazadeh B. Hallmark of opium poisoning in infants and toddlers. Trop Doct 2010; 40(4):220-2. doi: 10.1258/td.2010.100134.

14. Imran M, Uppal TB. Opium administration to infants in Peshawar region of Pakistan. Bull Narc 1979; 31: 69-75.

15. Shah I. Opium intoxication in an infant on Indian folk medicine. J Nat Sci Biol Med 2012; 3(2):201-2.

16. Trinh-Thi-Minh-HA, Nguyen-Hoc-Huong-Thu. Opium poisoning in Vietnamese infants. South East Asiaian J Trop Med Public Health 1973; 4: 593-5. 